\title{
Dicella a Genus of Malpighiaceae New to Colombia
}

\author{
William R. Anderson $\left({ }^{*}\right)$
}

\begin{abstract}
The genus Dicella (Malpighiaceae) has been collected for the first time in Colombia by $\mathrm{Dr}$. Djaja D. Soejarto. The species is Dicella juliani: (Macbride) W. R. Anderson, comb. nov. It is described, illustrated, and compared to its nearest relative, D. conwayi. The phytogeographic significance of this trans-Andean disjunct from Amazonia is discussed in relation to Haffer's theory of Pleistocene forest refuges.
\end{abstract}

Dr. Djaja D. Soejarto has discovered in the Colombian state of Antioquia a population of Dicella, a genus which was not known to occur in Colombia when Cuatrecasas wrote his excellent treatment of Malpighiaceae for the Prima Flora Colombiana (1958). Dr. Soejarto's discovery is particularly intriguing because the plants are growing north of the Andes, far from their nearest relatives in Amazonian Perú and Brazil. The following treatment for Dicella in Colombia is offered as a supplement to Cuatrecasas's Flora, in the hope trat it will facilitate the recognition of additional Colombian populations. The description combines characters useful at the generic and specific levels.

Dicella julianii (Macbride) W. R. Anderson, comb. nov.

Tetrapterys julianii Macbride, Flora of Perú, Field Mus. Nat. Hist., Bot. Ser. 13 (pt. 3): 805. 1950. (Published as "Tetrapteris Juliani") Type: Klug 347 (US! holotype, NY! isotype).

Dicella amazonica Pires, Bol. Técn. Inst. Agron. N. 38: 27. 1960. Type: Fróes 23797 (IAN! holotype \& isotype).

Woody liana climbing to $30 \mathrm{~m}$, the younger stems and inflorescence golden - or brownishsericeous. Leaves with obscure interpetiolar stipules to $0.5 \mathrm{~mm}$ long; petiole $1.3-2.4 \mathrm{~cm}$ long, persistently sericeous, eglandular or bearing 2 small glands above middle on adaxial edges; lamina 10-16 cm long, 5. 0-8.5 cm wide, elliptic, acute or rounded at the base, abruptly narrowed to an acuminate apex, with the reticulum prominent below and usually prominent above, eglandular or bearing several minute marginal glands, glabrate adaxially, persistently, sericeous abaxially. Inflorescence terminal or axillary, paniculate, with flowers in the ultimate pseudoracemes strictly decussate; bracts (4-) 5-7 mm long, 3-5 mm wide, elliptic, acute or obtuse at the apex, usually revolute, eglandular, adaxially glabrous except pilose at the apex, abaxially sericeous; peduncle 5-7 mm long, sericeous, apically bibracteolate, the bracteoles $3-5 \mathrm{~mm}$ long, $2-4 \mathrm{~mm}$ wide, obovate or orbicular and broadly rounded at the apex, otherwise like the bracts; bracts and bracteoles deciauous in fruit; pedicel $5-7 . \mathrm{mm}$ long in flower, up to $15 \mathrm{~mm}$ long in fruit, sericeous. Sepals $5,2 \mathrm{~mm}$ wide, obtuse or rounded at the apex, adaxially glabrous, abaxially sericeous, pressed in against the androecium after anthesis, the 4 lateral sepals bearing 8 elliptic, glabrous glands $2.5-4.0 \mathrm{~mm}$ long, the sepals exceeding the glands by $2 \mathrm{~mm}$. Petals 5, yellow, clawed, spreading between the sepals, adaxially glabrous, abaxially sericeous with the hairs finer and whiter on the limb than on the claw; 4 lateral petals with the claw $1.5-2.0 \mathrm{~mm}$ long, the limb $7.0-9.0 \mathrm{~mm}$ long and $5 \cdot 0.6 .5 \mathrm{~mm}$ wide, obovate or orbicular truncate or subauriculate at the base, erose or denticulate at the margin, the anterior pair larger than the posterior pair; posterior, "flag" petal with stout claw $3.5-4.5 \mathrm{~mm}$ long, limb $4 \cdot 0-6.0 \mathrm{~mm}$ long and $3 \cdot 0-5.0 \mathrm{~mm}$ wide, broadly elliptic, cuneate at the base, with marginal glands on the proximal half of the limb. Stamens 10 in 1 whorl, with the filaments

( ) - The University of Michigan Herbarium, Ann Arbor. Michigan, U.S.A. 
2.0-2.5 mm long, connate for $1.5 . \mathrm{mm}$ or more, adaxially glabrous, abaxially sericeous, persistent in fruit; anthers $1.5-2.5 \mathrm{~mm}$ long, strongly reflexed after anthesis, \pm alike except for 2 smaller ones opposite the anterior petals; locules $1.0-1.7 \mathrm{~mm}$ long, pendulous up to 0.5 $\mathrm{mm}$ below insertion of the filament, tapered distally, densely pilose-sericeous; connective dark red, cylindrical or slightly swollen distally, elongated and exceeding the locules by up to $1.0 \mathrm{~mm}$. Ovary $2 \mathrm{~mm}$ high, sericeous, formed from 3 connate carpels, the 2 posterior carpels full-sized and each containing 1 ovule in its own locule, the anterior carpel rudimentary and empty; styles 2, free, $2 \mathrm{~mm}$ long, stout and straight, glabrous, obliquely truncate at the apex with the large internal stigmas twisted toward the posterior petal; third, anterior style often present as a short, slender rudiment between the other 2 and opposite the anterior sepal. Fruit composed of a nut subtended by 5 wings; nut spherical, $1.3-1.8 \mathrm{~cm}$ in diameter, brown and dry at maturity, sericeous to glabrate, with a thick, fibrous, indehiscent wail enclosing 1 or 2 seeds with persistent perisperm; wings formed by enlargement of the sepals, dry at maturity, $2.0-5.5 \mathrm{~cm}$ long, $0.7-1.6 \mathrm{~cm}$ wide, narrowly elliptic or obovate, abaxially sericeous to glabrate, unequal, the posterior-lateral pair longest, the anteriro-lateral pair intermediate, and the anterior (glandless) one smallest. Figure 1.

SPECIMENS EXAMINED. COLOMBIA. Antioquia. Município de Anorí, Corregimiento de Providencia, Tirana Creek, secondary forest, at the confluence with Rio Anorí, $5 \mathrm{~km}$ from Providencia, elev. 4.00-700 m, 23 Oct 1972, Soejarto $\mathbf{3 4 5 1}$ (Univ. Antio. quia); 24-31 May 1973, Soejarto et al. 4075 (NY); 6-12 Sep 1973, Soejarto et al. 425\% (NY) \& 4259 (MICH, NY). BRAZIL. Amazonas. Rio Solimões, Município de São Paulo de Olivença, upper Igarapé Belém, border of creek, 22 Dec 1948, Fróes 23797 (IAN, type of Dicella amazonica). Basin of Rio Negro, Tapuruquara, island in river, forest on terra firme, 20 Oct 1971, Prance et al. 15737 (INPA, MICH, NY). Rio Negro, Rio Cauaburí, Rio Maturacá, between Camp Tatú and Camp III, elev. 400-200 m, 22 Dec 1965, N. T. Silva \& Brazão 60722 [number series of Bassett Maguire] (F, IAN, MICH, NY. UB, US). PERÚ. Loreto. Mishuyacu, near Iquitos, elev. $100 \mathrm{~m}$, forest, Oct-Nov 1929, Klug 347 (NY, US, type of Tetrapterys julianii), Feb-Mar 1930, Klug 894 (NY, US).
Dr. Soejarto's plants agree in most characters with the type of Dicella julianii and with the other collections seen. The most striking difference is that the fruits of Soejarto 3451 have much smaller wings than do other fruiting collections; however, the, fruits of Soejarto 3451 were immature, so it is possible that the Colombian plants will prove to have typical fruits when they are collected at maturity.

Dicella julianii is a segregate from the widespread Amazonian species $D$. conwayi Rusby (Fig. 2). These two species can be distinguished morphologically in the following manner :

Filaments connate for about $3 / 4$ or more of their length (1 filament sometimes nearly free), abaxially sericeuos for most or all of their length; locules of the anthers not or only slightly pendulous below the insertion of the filament, densely and persistently pilosesericeous for their whole length; hairs on limb of petal finer and whiter than those of the claw and sepal.

D. julianii

Filaments only basally connate, up to $1 / 2$ of their length, abaxially sericeous in the proximal $1 / 2$ only; locules of the anthers pendulous, hanging well below the insertion of the filament, giabrous or sparsely pilose at base; hairs of whole petal and sepal more or less alike. .

D. conwayi

Dicella julianii and $D$. conwayi can be distinguished from $D$. macroptera of southcentral Brazil on the basis of the leaf hairs, which are sinuous and loose in D. macroptera, straight and sessile in $D$. julianii and $D$. conwayi.

As Figure 2 shows, the four previously known collections of Dicella julianii are from the Amazonian lowlands of Brazil and Perú, forming a pattern of distribution which is shared with a number of Amazonian species. Further collection will very probably reveal other populations in northwestern Amazonia. However, the discovery of a disjunct population in trans-Andean Colombia is surprising and requires explanation. Haffer (1969), has pos- 


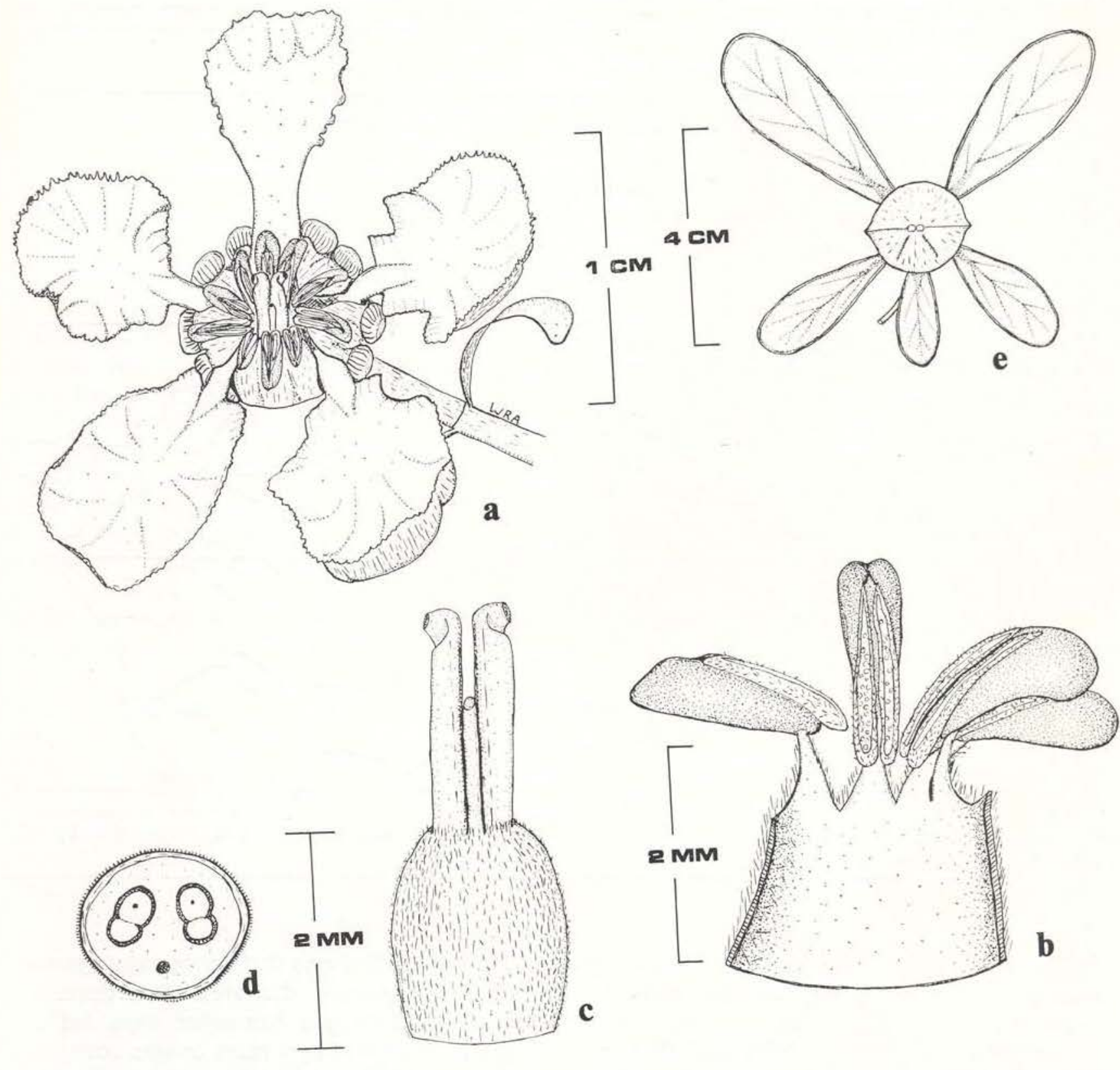

Figure 1. Dicella julianii: a, flower; b, portion of androecium, spread open; c, gynoecium; d, cross-section of ovary, showing 2 locules fertile and 1 rudimentary: e, fruit. a-d, Soejarto 4257; e, Fróes 23797.

tulated that "during several dry climatic periods of the Pleistocene and post-Pleistocene. the Amazonian forest was diviaed into a number of smaller forests which were isolated from each other by tracts of open, nonforest vegetation. The remaining forests served as 'refuge areas' for numerous populations of forest animals, which deviated from one another during periods of geographic isolation"
Haffer recognized his refuge areas on the bases of geologic and climatic history and, more importantly, the present distributions of disjunct and endemic populations of birds. Prance (1973) points out that the present distributions of forest plant species should be considered in defining such refuges; his data generally support Haffer's refuges. One of Haffer's trans-Andean refuges is called the 


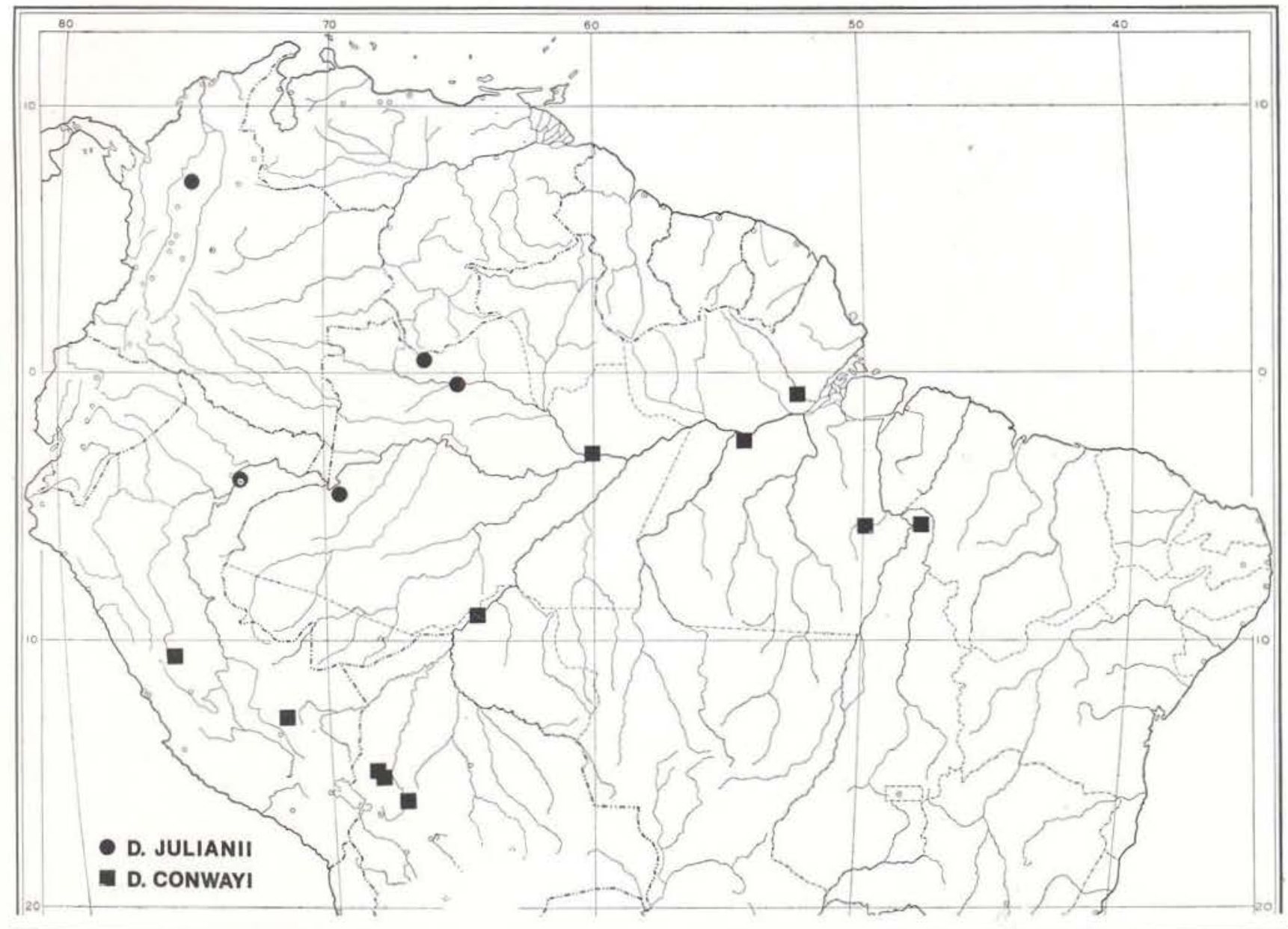

Figure 2. Distribution of Dicella julianii and D. conwayi. (Goode Base Map N.॰ 103, Copyright by The University of Chicago).

Nechi refuge, named for the Rio Nechí and located "in forests along the the northern foothills and adjacent lowlands of the Central and Western Cordillera of Colombia" (Haffer, 1967). That is precisely the area where Dr. Soejarto found the population of Dicella discussed in this paper. Its presence there would seem to support recognition of the Nechí area as a refuge. Presumably $D$. julianii reached that area during a humid period when the forest was more or less continuous and the species had a much more extensive range than at present. That range probably contracted during a drier period, at which time the Nachi population was isolated, and subsequently the species seems not to have re-expanded its range even when the forest expanded. One wonders what may have been the route by which Dicella arrived at the Nechí area. Haffer
(1967, pp. 6-8) shows that during humid periods of the Pleistocene the area of northwestern South America was somewhat expanded and probably covered by a more or less continuous forest across the present-day llanos of eastern Colombia. Such a forest would connect the upper Rio Negro with northwestern Colombia. Haffer feels that was the route followed by most birds, and I agree that it is the most likely route for Dicella. However, Haffer also suggests that "the narrowing Andes to the south seem to offer several pathways for Amazonian forms to reach the Pacific lowlands in northern Perú and southern Ecuador" (1967. p. 23), and a few birds do seem to have taken that route from Amazonia to trans-Andean Colombia. Since Dicella julianii has been collected near Iquitos in Perú, such a Pacific route is at least theoretically possible. There 
are many Anderson, Dicella in Colombia, p. 8 phytogeographic surprises still awaiting us in the forests of South America, as Dr. Soejarto has demonstrated, and perhaps additional relict populations of Dicella will be found that will support one route or the other.

\section{ACKNOWLEDGEMEMTS}

The author gratefully acknowledges support of his research on the systematics of Malpighiaceae by National Science Foundation Grants GB-37314 and GF-42557 to The New York Botanical Garden.

\section{RESUMO}

O gênero Dicella (Malpighiaceae) foi coletado pela primeira vez na Colômbia, pelo Dr. Djaja D. Soejarto. A espécie é Dicella julianii (Macbride) W. R. Anderson, comb. nov., que se descreve, ilustra e contrasta com a espécie mais afim,
D. conwayi. Discutida a significação fitogeográfica desta população disjunta transandina, em relação à teoria de Haffer, de refúgios de mata no Pleistoceno.

\section{'LTTERATURE CITED}

Cuatrecasas, José

1958 - Prima Flora Colombiana, 2. Malpighiaceae. Webbia, 13(2) : 343-664.

HAFFER, JÜRgEN

1967 - Speciation in Colombian forest birds west of the Andes. American Museum Novitates, $2294: 1-57$.

1969 - Speciation in Amazonian forest birds. Science, $165: 131-137$.

Prance, Ghillean T,

1973 - Phytogeographic support for the theory of Pleistocene forest refuges in the Amazon Basin, based on evidence from distribution patterns in Caryocaraceae, Chrysobalanaceae, Dichapetalaceae and Lecythidaceae. Acta Amazonica, Manaus, $3(3): 5-28$. 